\title{
Surface Modification of Addition Manufactured Ti-6Al-4V Alloys by Ultraviolet Pulsed Laser Scanning Technique: Morphologies, Roughness And Electrical Properties
}

\author{
Chien-Fang Ding ${ }^{1}$, Yi-Cheng Lin ${ }^{1}$, Ching-Ching Yang ${ }^{1}$, Chun-Ming Chang ${ }^{1}$, Kuo-Cheng Huang ${ }^{1}$, Shih-Feng Tseng ${ }^{2}$, Keh- \\ Moh Lin ${ }^{3}$ and Wen-Tse Hsiao*1 \\ ${ }^{1}$ Taiwan Instrument Research Institute, National Applied Research Laboratories, Taiwan, No.20, \\ R\&D Rd. VI, Hsinchu Science Park, Hsinchu City, 300092, Taiwan \\ ${ }^{2}$ Department of Mechanical Engineering, National Taipei University of Technology, Taiwan, No.1, \\ Sec. 3, Zhongxiao E. Rd., Taipei City, 10608, Taiwan \\ ${ }^{3}$ Department of Mechanical Engineering, Southern Taiwan University of Science and Technology, \\ Taiwan, No.1, Nan-Tai St., Yungkang Dist., Tainan City, 71005, Taiwan \\ *Corresponding author's e-mail: wentse@narlabs.org.tw
}

\begin{abstract}
Titanium-aluminum-vanadium (Ti-6Al-4V) alloys are widely used in medical components owing to their excellent biocompatibility with human cells and mechanical properties. To provide a habitat for bone cells such as osteoblasts and osteoclasts and increase bone strength at the boneimplant interface, several investigators have created cavities or textures on Ti-6Al-4V alloys to increase the surface roughness of the alloys and enhance cell adhesion and osseointegration. In this study, titanium alloy blocks were fabricated using selective laser melting. Additively manufactured solid blocks measuring $10 \mathrm{~mm} \times 10 \mathrm{~mm} \times 8 \mathrm{~mm}$ served as the study samples, and they were not subjected to any post-processing; however, they were subjected to laser surface modification. Experimental results revealed that the laser power and modification speed had a considerable effect on the surface roughness of the Ti-6Al-4V samples. Furthermore, the electrical resistivity of the samples was investigated after the laser surface modification process.
\end{abstract}

DOI: $10.2961 /$ jlmn.2021.01.2005

Keywords: Ti-6Al-4V alloys, additive manufacturing, selective laser melting, laser surface modification, surface roughness, electrical resistivity.

\section{Introduction}

Titanium-aluminum-vanadium $(\mathrm{Ti}-6 \mathrm{Al}-4 \mathrm{~V})$ alloys have been widely used in biomedical engineering owing to their superior properties, such as high biocompatibility, high tensile strength, and high corrosion resistance, compared with other metallic biomaterials [1-3]. However, when these alloys are used as a material in implants for the human body, they may be subjected to considerable wear and corrosion [4-6]. Several surface modification techniques have been proposed to address this issue. Ion implantation has been employed to modify the surface of various materials, including polymers [7], stainless steel [8], aluminum alloys [9], ceramics, and titanium alloys [10]; the hardness and wear resistance of materials increase with the ion fluence. Furthermore, laser surface modification has been identified as a promising approach to improve the physical properties, including mechanical and tribological properties, of materials. Jervis et al. [11] used an excimer laser $(248 \mathrm{~nm})$ in the surface modification of a Ti-6Al-4V alloy in air, and the result indicated that the surface hardness of the Ti-6Al-4V alloy increased and was approximately two times that of an electropolished $\mathrm{Ti}-6 \mathrm{Al}-4 \mathrm{~V}$ alloy. Schnell et al. [12] produced nano- and microstructures on the surface of a Ti-6Al-4V alloy by using a femtosecond fiber laser (center wavelength $=1030 \mathrm{~nm}$; pulse duration $=300 \mathrm{fs}$ ); they examined the wettability and surface roughness of the laser-structured $\mathrm{Ti}-6 \mathrm{Al}-4 \mathrm{~V}$ samples and demonstrated the suitability of laser-based surface modification processes in regenerative medicine. They revealed enhanced cellular adhesion and cellular growth on the laser-processed structure. Shaikh et al. [13] applied laser treatment to $\mathrm{Ti}-6 \mathrm{Al}-4 \mathrm{~V}$ by using a Ti:sapphire femtosecond laser (center wavelength $=800 \mathrm{~nm}$; pulse duration $=$ $45 \mathrm{fs}$ ). This inhibited the growth of bacteria on $\mathrm{Ti}-6 \mathrm{Al}-4 \mathrm{~V}$, which can be used as a material in dental and orthopedic implants. However, the use of excimer lasers and femtosecond lasers is not suitable for industrial applications because they are complex, expensive, and require frequent maintenance. Man et al. [14] executed a continuous-wave (CW) Nd:YAG laser surface nitriding process on a $\mathrm{Ti}-$ $6 \mathrm{Al}-4 \mathrm{~V}$ alloy to produce a matrix of $\mathrm{TiN}$ dendrites in a $\mathrm{Ti}$ alloy. This increased the surface area and introduced a locking mechanism to facilitate surface coating. In addition, the condition of the surface of the material (i.e., surface roughness) considerably influences implant biocompatibility in vivo [15], antibacterial properties [16], and mechanical properties [17]. Laser polishing has been considered a novel approach, compared with conventional mechanical polishing methods, for modifying surface morphology and roughness effectively with minimal effects on the bulk property of the material. Perry et al. [18] performed pulsed laser micropolishing to reduce the surface roughness of 
micromilled Ti-6Al-4V samples by using a 1064-nm $\mathrm{Nd}$ :YAG laser. The results revealed that the average surface roughness was reduced from 0.206 to $0.070 \mu \mathrm{m}$, with an inert shielding gas being used to prevent cracks on the material surface. Marimuthu et al. [19] used a CW fiber laser $(1070-1090 \mathrm{~nm})$ to polish $\mathrm{Ti}-6 \mathrm{Al}-4 \mathrm{~V}$ components (manufactured through selective laser melting (SLM)) without causing any significant changes to the material characteristics; they achieved a remarkable reduction in the surface roughness (from $10.2 \mu \mathrm{m}$ to $2.4 \mu \mathrm{m}$ ). Giorleo et al. [20] performed a polishing process on a Ti sheet by using a $\mathrm{Nd}: \mathrm{YVO}_{4}$ laser $(532 \mathrm{~nm})$ and examined the effects of laser paths and assist gas on the reduction of $\mathrm{Ti}$ sheet surface roughness. Ma et al. [21] conducted a polishing process on additively manufactured (AM) Ti-based alloys (i.e. Ti$6 \mathrm{Al}-4 \mathrm{~V}$ and $\mathrm{TC} 11)$ by using a nanosecond pulsed fiber laser $(1060 \mathrm{~nm})$; the surface roughness of the alloys was reduced from more than $5 \mu \mathrm{m}$ to less than $1 \mu \mathrm{m}$.

In the present study, a pulsed ultraviolet laser scanning system with a wavelength of $355 \mathrm{~nm}$ was used in the surface modification of AM Ti-6Al-4V samples, which were fabricated using SLM without posttreatment. The surface morphology, surface roughness, and electrical resistivity of the laser-modified Ti-6Al-4V alloy were investigated.

\section{Experimental details}

Ti-6Al-4V alloy blocks measuring $10 \mathrm{~mm} \times 10 \mathrm{~mm} \times$ $8 \mathrm{~mm}$ were fabricated using an SLM system (AM 250, Renishaw plc, UK), as illustrated in Figure 1. The surface roughness $\left(\mathrm{R}_{\mathrm{a}}\right)$ of the blocks was $1.96 \pm 0.46$ $\mu \mathrm{m}$, and there was negligible oxygen content due to its high oxidation resistance.

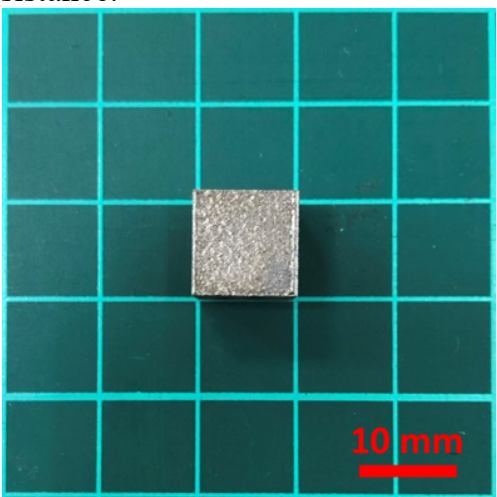

Fig. 1 A photo of AM fabrication Ti-6Al-4V alloy block.

A diode-pumped solid-state (DPSS) ultraviolet laser system was used in this study (Figure 2). The laser system was determined to have a center wavelength of $355 \mathrm{~nm}$, a pulse width of $<40 \mathrm{~ns}$ at a $100-\mathrm{kHz}$ pulse repetition rate, a maximum output power of $14 \mathrm{~W}$, a $\mathrm{TEM}_{00}$ mode, and an output laser beam diameter of $3.5 \mathrm{~mm}$. The system also included a dual-axis high-speed galvanometer scanner embedded with a focus shifter to adjust the focus range in the Z-direction from $+15 \mathrm{~mm}$ to $-15 \mathrm{~mm}$. A telecentric lens (ftheta lens) with a focal length of $110 \mathrm{~mm}$, focused laser beam diameter of $30 \mu \mathrm{m}$, and maximum scanning area of $50 \mathrm{~mm}^{2}$ was used in the surface modification process to obtain the finished surface on each Ti-6Al-4V alloy block.

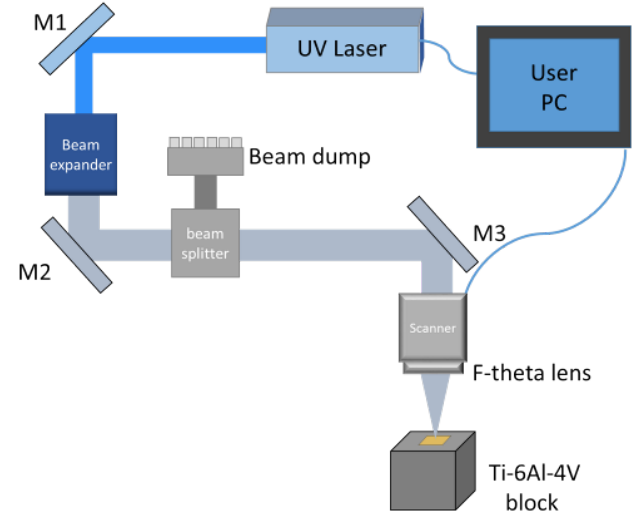

Fig. 2 Schematic of the laser surface modification processing system.

The arithmetic average surface roughness $\left(R_{a}\right)$ was evaluated using a three-dimensional (3D) laser scanning confocal microscope (Keyence VK-X200K), and the electrical resistance of the $\mathrm{Ti}-6 \mathrm{Al}-4 \mathrm{~V}$ alloy blocks was analyzed using van der Pauw's method [22]. The experiment and measurements for all modified samples were taken 5 times to show the reproducibility.

In this study, the laser pulse repetition frequency was maintained at $100 \mathrm{kHz}$, and the laser power was varied from 1 to $5 \mathrm{~W}$. Different surface modification speeds (700, 900, and $1100 \mathrm{~mm} / \mathrm{s}$ ) were applied, and the cross-hatching path spacing (X-direction and $\mathrm{Y}$-direction) was maintained at $0.01 \mathrm{~mm}$ (Figure 3).

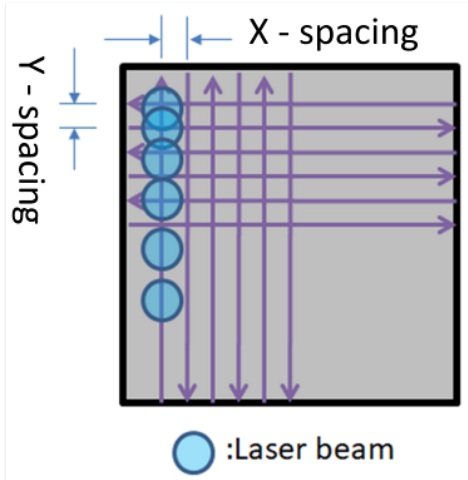

Fig. 3 Cross-hatching path for laser modification.

\section{Results and discussion \\ 3.1 Morphology characterization}

The surface morphologies of the as-received AM Ti$6 \mathrm{Al}-4 \mathrm{~V}$ samples was evaluated using the 3D laser scanning confocal microscope (measured area $=94.9 \mu \mathrm{m} \times 71.2 \mu \mathrm{m}$ ). Figures 4-6 illustrate the surface morphologies of the lasermodified AM Ti-6Al-4V samples under different laser power levels and modification speeds. As the laser power increased and the modification speed decreased, distinct cracks were observed on the sample surface (Figure 6). 
(a)

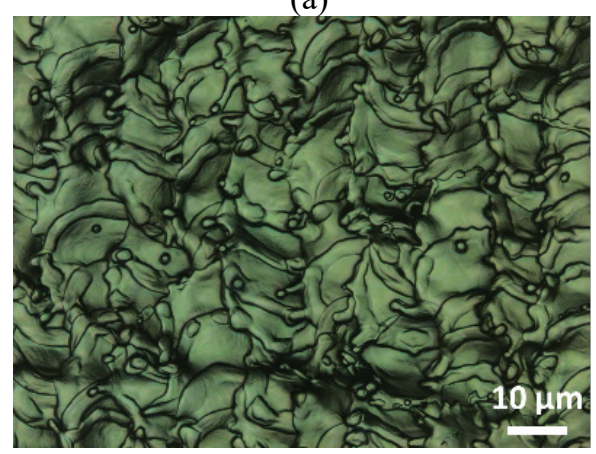

(b)

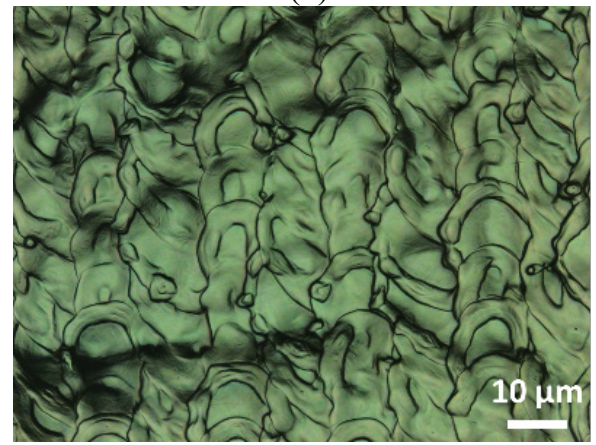

(c)

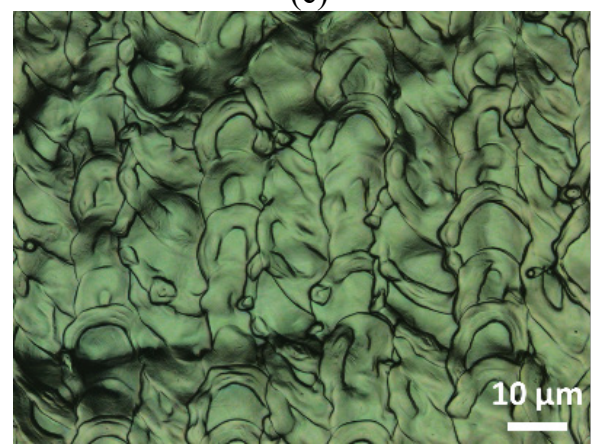

Fig. 4 Surface morphology of laser-modified AM Ti-6Al-4V sample with a laser power of $1 \mathrm{~W}$ and (a) modification speed $=$ $700 \mathrm{~mm} / \mathrm{s}$, (b) modification speed $=900 \mathrm{~mm} / \mathrm{s}$, and (c) modification speed $=1100 \mathrm{~mm} / \mathrm{s}$.

(a)

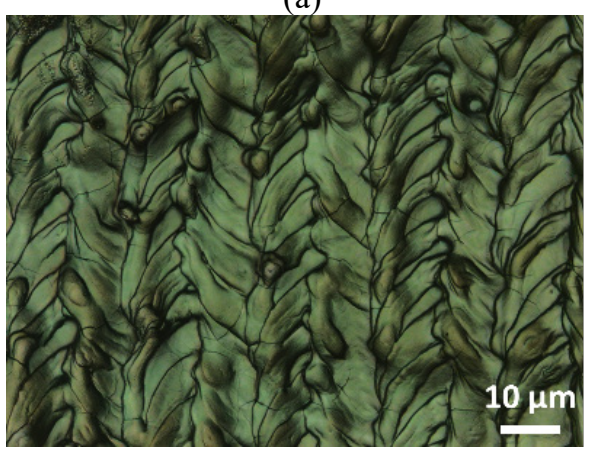

(b)

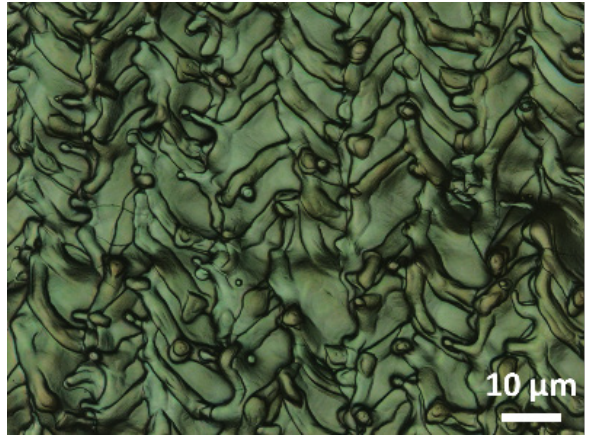

(c)

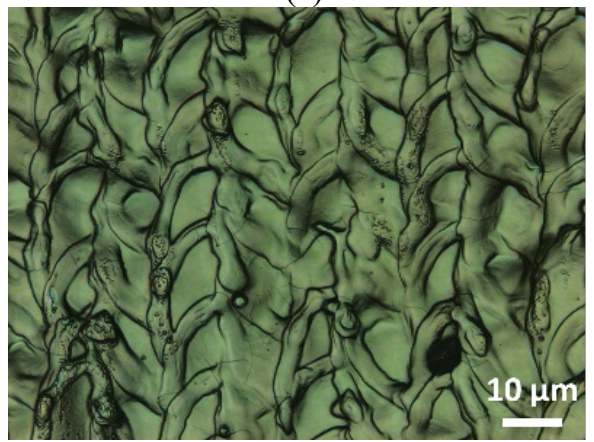

Fig. 5 Surface morphology of laser-modified AM Ti-6Al-4V sample with a laser power of $3 \mathrm{~W}$ and (a) modification speed $=$ $700 \mathrm{~mm} / \mathrm{s}$, (b) modification speed $=900 \mathrm{~mm} / \mathrm{s}$, and (c) modification speed $=1100 \mathrm{~mm} / \mathrm{s}$.

(a)

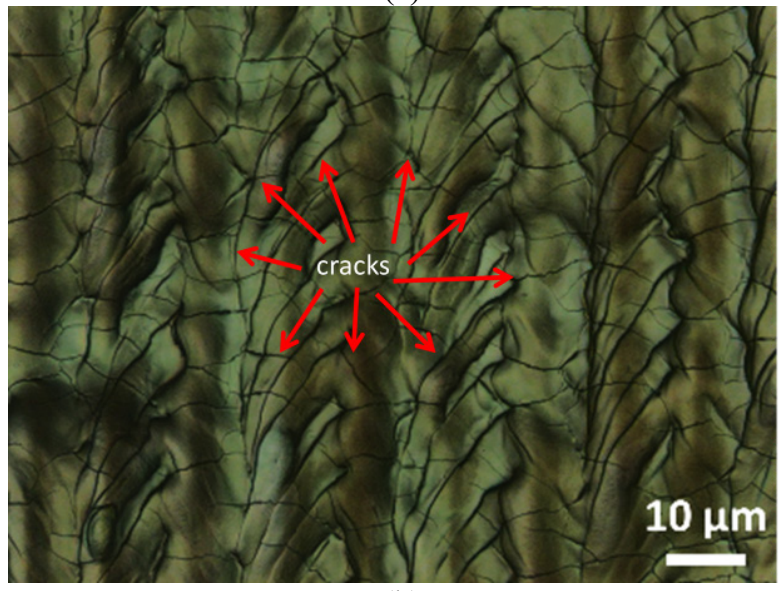

(b)

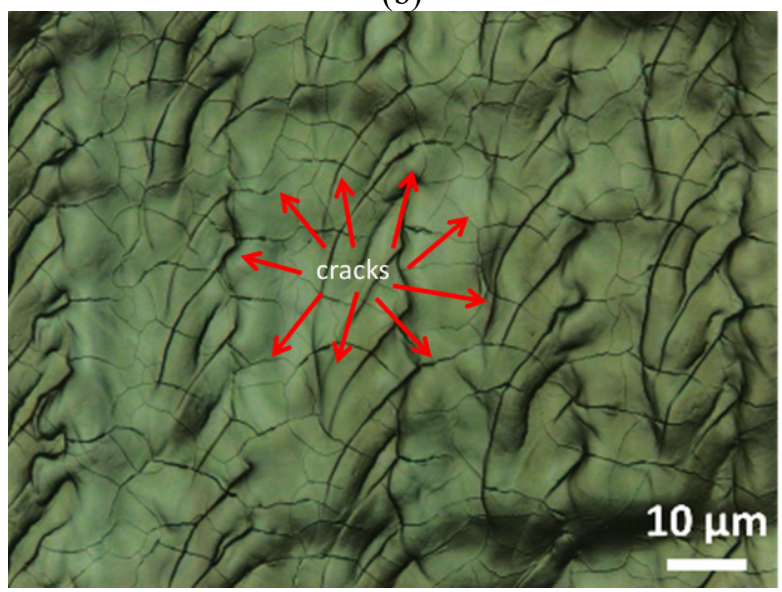

(c) 


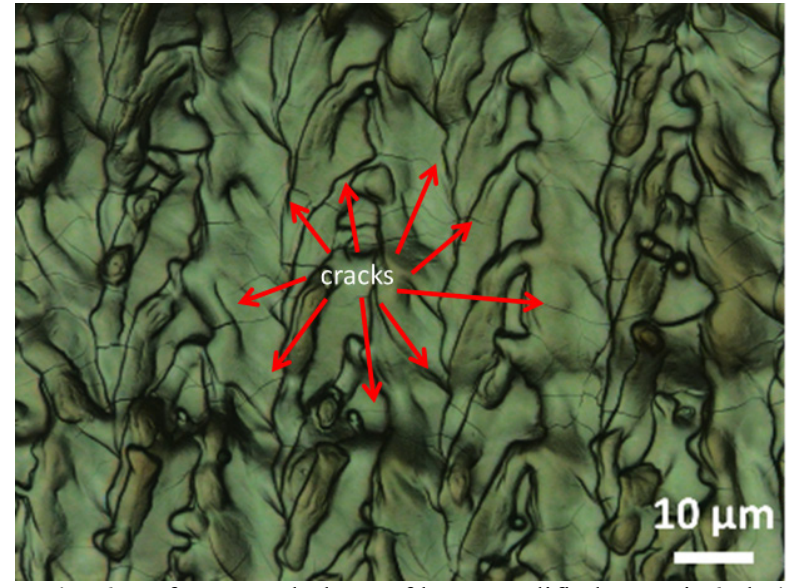

Fig. 6 Surface morphology of laser-modified AM Ti-6Al-4V sample with a laser power of $5 \mathrm{~W}$ and (a) modification speed $=$ $700 \mathrm{~mm} / \mathrm{s}$, (b) modification speed $=900 \mathrm{~mm} / \mathrm{s}$, and (c) modification speed $=1100 \mathrm{~mm} / \mathrm{s}$.

\subsection{Three-dimensional morphological and surface roughness characterization}

Figures 7-9 display the 3D surface topography of the AM Ti-6Al-4V samples after laser surface modification. Figure 10 presents the surface roughness of the Ti-6Al-4V samples under different laser surface modification parameters. The results indicated that the laser power increased as the surface roughness decreased. When the laser power was $1 \mathrm{~W}$, the surface roughness was reduced compared with the original surface. When there was more laser power (i.e. $3 \mathrm{~W}$ and $5 \mathrm{~W}$ ) applied, the lower surface roughness was obtained which was because of the more heat accumulation on the surface. After laser surface modification, the surface roughness of all AM Ti-6Al-4V samples was reduced relative to the surface roughness of the as-received samples $\left(\mathrm{R}_{\mathrm{a}}\right.$ $=1.96 \pm 0.46 \mu \mathrm{m})$. When the laser power was increased to $5 \mathrm{~W}$ and the modification speed was $700 \mathrm{~mm} / \mathrm{s}$, the surface roughness was lowest $(0.90 \pm 0.06 \mu \mathrm{m})$. This was because the laser-generated heat on the surface could ablate more material, leading to a lower surface roughness; however, when the modification speed was more than $900 \mathrm{~mm} / \mathrm{s}$, a small amount of ablation was observed on the surface, but the surface roughness was still lower than that of the asreceived samples.

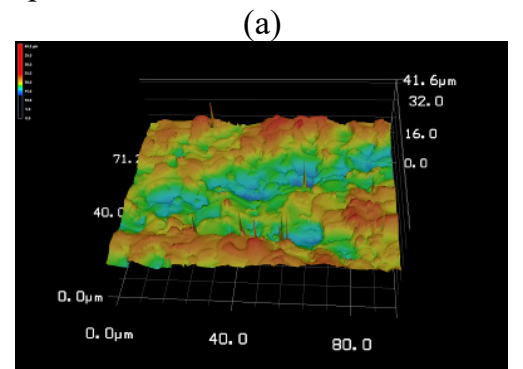

$\mathrm{R}_{\mathrm{a}}=1.53 \pm 0.03 \mu \mathrm{m}$ (b)

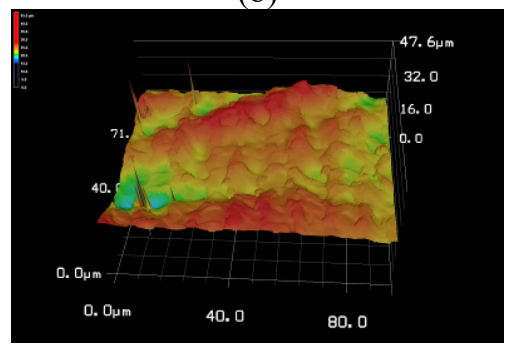

$\mathrm{R}_{\mathrm{a}}=1.58 \pm 0.14 \mu \mathrm{m}$

(c)

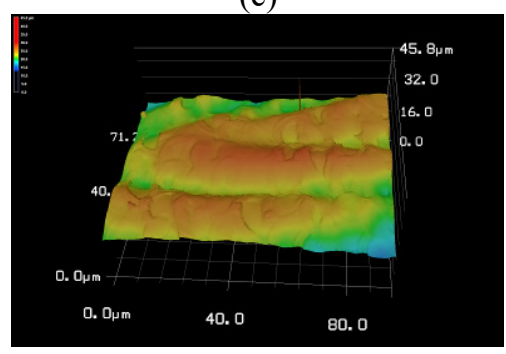

$\mathrm{R}_{\mathrm{a}}=1.72 \pm 0.03 \mu \mathrm{m}$

Fig. 7 Three-dimensional surface morphology of laser-modified AM Ti-6Al-4V sample with a laser power of $1 \mathrm{~W}$ and (a) modification speed $=700 \mathrm{~mm} / \mathrm{s}$, (b) modification speed $=900 \mathrm{~mm} / \mathrm{s}$, and (c) modification speed $=1100 \mathrm{~mm} / \mathrm{s}$.

(a)

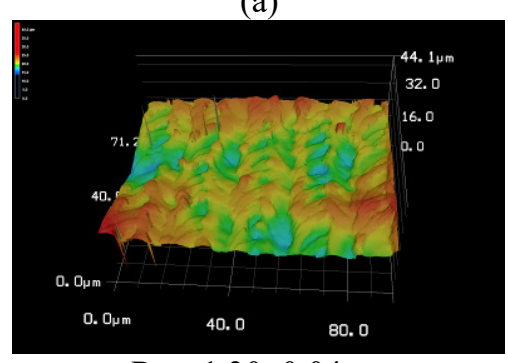

$\mathrm{R}_{\mathrm{a}}=1.30 \pm 0.04 \mu \mathrm{m}$

(b)

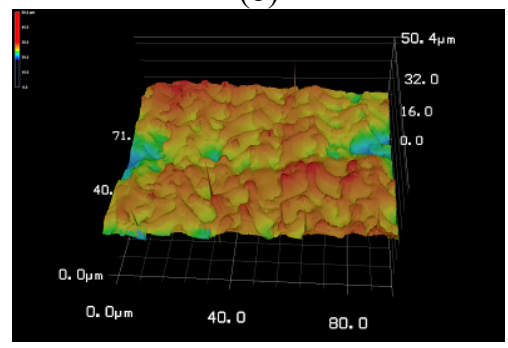

$\mathrm{R}_{\mathrm{a}}=1.20 \pm 0.13 \mu \mathrm{m}$

(c)

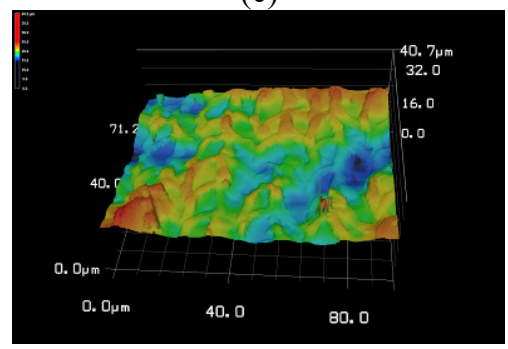

$\mathrm{R}_{\mathrm{a}}=1.35 \pm 0.09 \mu \mathrm{m}$

Fig. 8 Three-dimensional surface morphology of laser-modified AM Ti-6Al-4V sample with a laser power of $3 \mathrm{~W}$ and (a) modification speed $=700 \mathrm{~mm} / \mathrm{s}$, (b) modification speed $=900 \mathrm{~mm} / \mathrm{s}$, and

(c) modification speed $=1100 \mathrm{~mm} / \mathrm{s}$. 
(a)

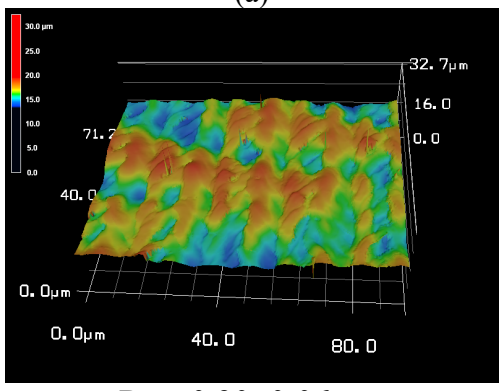

$\mathrm{R}_{\mathrm{a}}=0.90 \pm 0.06 \mu \mathrm{m}$

(b)

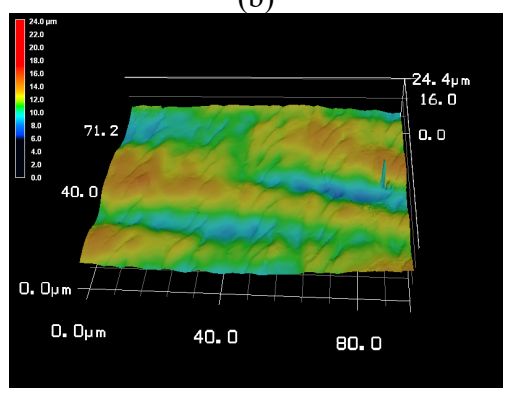

$\mathrm{R}_{\mathrm{a}}=1.00 \pm 0.08 \mu \mathrm{m}$

(c)

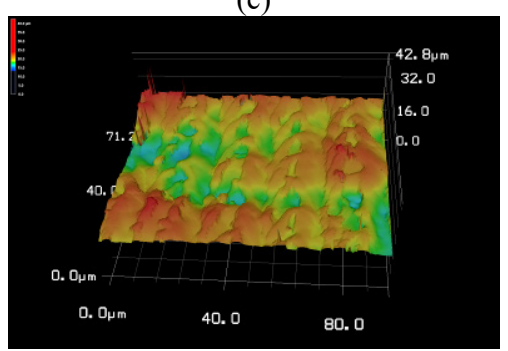

$\mathrm{R}_{\mathrm{a}}=1.30 \pm 0.03 \mu \mathrm{m}$

Fig. 9 Three-dimensional surface morphology of laser-modified AM Ti-6Al-4V sample with a laser power of $5 \mathrm{~W}$ and (a) modification speed $=700 \mathrm{~mm} / \mathrm{s}$, (b) modification speed $=900 \mathrm{~mm} / \mathrm{s}$, and

(c) modification speed $=1100 \mathrm{~mm} / \mathrm{s}$.

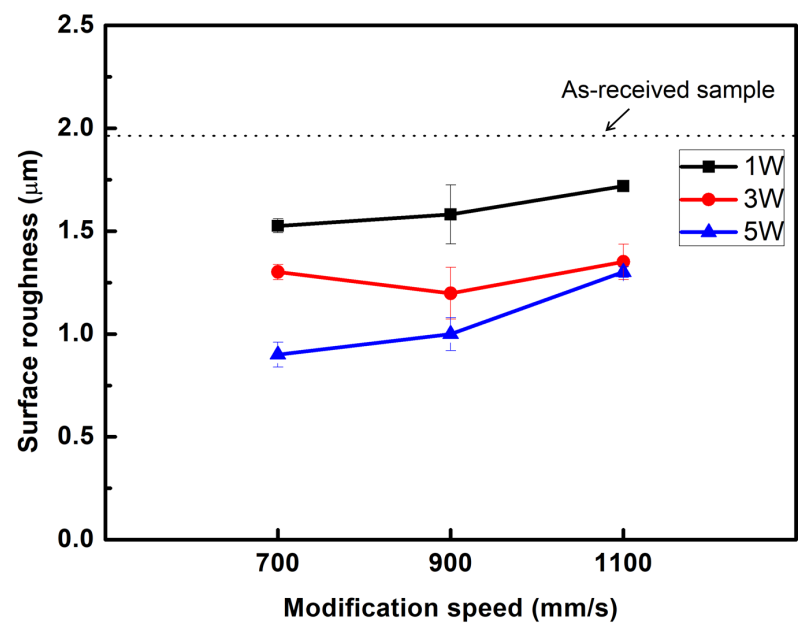

Fig. 10 Surface roughness of AM Ti-6Al-4V sample after laser surface modification under different laser power and modification speeds.

\subsection{Electrical resistivity analysis}

Figure 11 shows the electrical resistance $(\mathrm{R})$ of the $\mathrm{Ti}-$ $6 \mathrm{Al}-4 \mathrm{~V}$ samples after laser surface modification. The elec- trical resistance increased as the laser power increased. One reason is the increased oxidation (see Table 1). Another reason could be the appearance of cracks by using $5 \mathrm{~W}$ average laser power (compare with Fig. 6). The electrical resistance decreased because the oxygen content decreased with increasing scanning speed, as shown in Fig. 12. This was caused by (high) oxygen content when the laser surface modification process was performed in the atmospheric environment which brought about the oxygen diffusion. When the modification speed was over $700 \mathrm{~mm} / \mathrm{s}$, there was negligible oxygen content since the high modification speed was not able to induce oxygen diffusion. Table 1 presents the electrical resistance and oxygen concentration $(w t \%)$ as a function of the laser modification parameters. When the laser power was up to $5 \mathrm{~W}$ and the modification speed was below $700 \mathrm{~mm} / \mathrm{s}$, the electrical resistance was $351.27 \pm 9.9 \Omega$, which was the highest value. However, when the laser power was $1 \mathrm{~W}$, the variation in the electrical resistance was very small, and the values were similar to those of the as-received samples $(\mathrm{R}=1.03 \pm 0.3 \Omega)$.

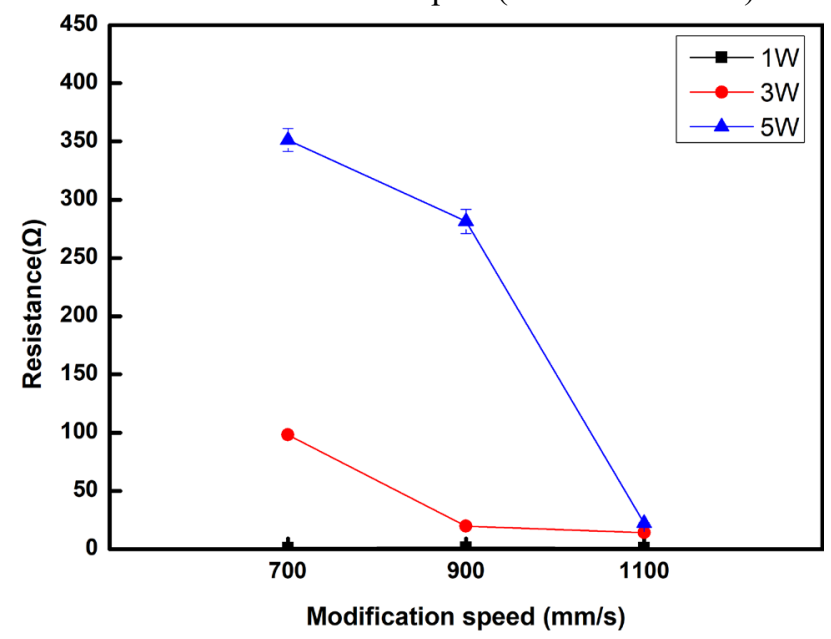

Fig. 11 Electrical resistance (Reviewer \# 1, Q3) of Ti-6Al-4V samples after laser surface modification under different laser power and modification speeds.

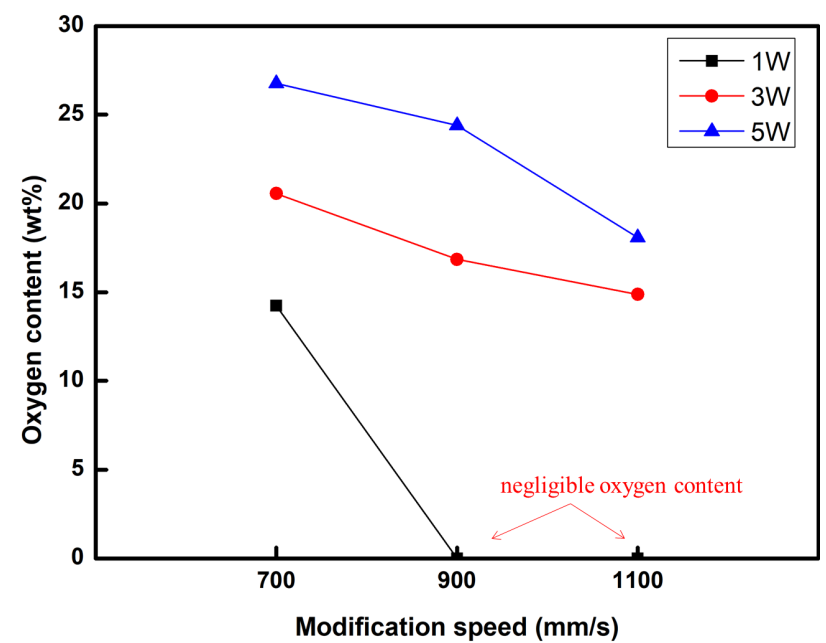

Fig. 12 Oxygen content of Ti-6Al-4V samples after laser surface modification under different laser power and modification speeds. 


\section{Table 1}

Electrical resistance as a function of the laser modification parameters.

\begin{tabular}{cccc}
\hline $\begin{array}{c}\text { Laser } \\
\text { power }(\mathrm{W})\end{array}$ & $\begin{array}{c}\text { Modification } \\
\text { speed }(\mathrm{mm} / \mathrm{s})\end{array}$ & $\begin{array}{c}\text { Oxygen } \\
(\text { wt. } \%)\end{array}$ & $\begin{array}{c}\text { Electrical re- } \\
\text { sistance }(\Omega)\end{array}$ \\
\hline \multirow{2}{*}{1} & 700 & 14.24 & $1.20 \pm 0.1$ \\
& 900 & - & $1.59 \pm 0.3$ \\
& 1100 & - & $1.26 \pm 0.1$ \\
\hline \multirow{3}{*}{3} & 700 & 20.56 & $98.05 \pm 0.5$ \\
& 900 & 16.85 & $19.77 \pm 0.7$ \\
& 1100 & 14.88 & $14.27 \pm 0.5$ \\
\hline & 700 & 26.76 & $351.27 \pm 9.9$ \\
& 900 & 24.4 & $281.35 \pm 10.3$ \\
& 1100 & 18.08 & $22.24 \pm 0.4$ \\
\hline
\end{tabular}

\section{Conclusions}

A DPSS UV (355 nm) laser system was used for the surface modification of AM Ti-6Al-4V alloy samples under different modification parameters, after which the surface roughness and electrical resistivity were investigated. The surface roughness varied with different laser surface modification parameters. After laser surface modification, the surface roughness of the AM Ti-6Al-4V alloy samples decreased to less than $1 \mu \mathrm{m}$, and the electrical resistivity of most of the AM Ti-6Al-4V alloy samples was higher than that of the as-received samples. The surface chemistry of the as-received and laser-modified $\mathrm{Ti}-6 \mathrm{Al}-4 \mathrm{~V}$ alloy samples will be investigated in future work.

\section{Acknowledgement}

The authors thank the Ministry of Science and Technology of Taiwan for financially supporting this research under contract nos. MOST108-2221-E-492-020, and the microstructure and component analysis measuring from Taiwan Instrument Research Institute Ms. Nancy Chu supports are also acknowledged.

\section{References}

[1] M. Nouari, M. Calamaz, and F. Girot: C. R. Mécanique, 336, (2008) 772.

[2] J. H. Qin, Q. Chen, C. Y. Yang, and Y. Huang: J. Alloy Compd., 654, (2016) 39.

[3] R. C. Petersen: Metals, 4, (2014) 549.

[4] J. J. Jacobs, A. K. Skipor, L. M. Patterson, N. J. Hallab, W. G. Paprosky, J. Black, and J. O. Galante: J. Bone Joint Surg. Am., 80, (1998) 1447.

[5] S. S. Leopold, R. A. Berger, L. Patterson, A. K. Skipor, R. M. Urban, and J.J. Jacobs: J. Arthroplasty, 15, (2000) 938.

[6] J. J. Jacobs, C. Silverton, N. J. Hallab, A. K. Skipor, L. Patterson, J. Black, and J. O. Galante: Clin. Orthop., 358, (1999) 173.

[7] P. Lipinski, D. Bielinski, W. Okrój, W. Jakubowski, L. Klimek, and J. Jagielski: Vacuum, 83, (2009) S200.

[8] D. Manova, J. W. Gerlach, F. Scholze, S. Mändl, and H. Neumann: Surf. Coat. Technol., 204, (2010) 2919.

[9] R. Figueroa, C. M. Abreu, M. J. Cristbal, and G. Pena: Wear, 276-277, (2012) 53.
[10] J. Jagielski, A. Piatkowska, P. Aubert, L. Thom, A. Turos, and A. A. Kader: Surf. Coat. Technol., 200, (2006) 6355

[11] T. R. Jervis, T. G. Zocco, K. M. Hubbard, and M. Nastasi: Metall. Trans., A 24, (1993) 215.

[12] G. Schnell, S. Staehlke, U. Duenow, J. B. Nebe, and H. Seitz, Materials, 12, (2019), 2210.

[13] S. Shaikh, S. Kedia, D. Singh, M. Subramanian, and S. Sinha: J. Laser Appl., 31, (2019), 022011.

[14] H. C. Man, N. Q. Zhao, and Z. D. Cui: Surf. Coat. Tech., 192, (2005) 341.

[15] M. Marticorena, G. Corti, D. Olmedo, and M. B. Guglielmotti: J. Appl. Phys., 59, (2007) 662.

[16] L. Liu, R. Bhatia, and T. J. Webster: Int. J. Nanomed., 12, (2017) 8711.

[17] S. A. Shalnova, O. G. Klimova-Korsmik, and M. O. Sklyar: Solid State Phenom., 284, (2018) 312.

[18] T. L. Perry, D. Werschmoeller, X. Li, F. E. Pfefferkorn, N. A. Duffie: J. Manuf. Process., 11, (2009) 74.

[19] S. Marimuthu, A. Triantaphyllou, M. Antar, D. Wimpenny, H. Morton, and M. Beard: Int. J. Mach. Tool Manu., 95, (2015) 97.

[20] L. Giorleo, E. Ceretti, and C. Giardini, Procedia CIRP, 33, (2015) 446.

[21] C. P. Ma, Y. C. Guan, and W. Zhou: Opt. Laser Eng., 93, (2017) 171.

[22] L. J. Pauw. van der: Philips Tech. Rev., 20, (1958) 1.

(Received: May 22, 2020, Accepted: December 9, 2020) 